\section{Brandeis $\left.\right|_{\text {wrewer }}$}

brandeis.edu/j-caste
CASTE: A Global Journal on Social Exclusion

Vol. 1, No. 1, pp. 51-70

February 2020

ISSN 2639-4928

DOI: 10.26812/caste.v1i1.145

\title{
Nationalism, Caste-Blindness, and the Continuing Problems of War-Displaced Panchamars in Post-War Jaffna Society
}

\author{
Kalinga Tudor Silva'
}

\begin{abstract}
More than a decade after the end of the 26-year old LTTE-led civil war in Sri Lanka, a particular section of the Jaffna society continues to stay as Internally Displaced People (IDP). This paper tries to unravel why some low caste groups have failed to end their displacement and move out of the camps while everybody else has moved on to become a settled population regardless of the limitations they experience in the post-war era. Using both quantitative and qualitative data from the affected communities the paper argues that ethnic-biases and 'caste-blindness' of state policies, as well as Sinhala and Tamil politicians largely informed by rival nationalist perspectives are among the underlying causes of the prolonged IDP problem in the Jaffna Peninsula. In search of an appropriate solution to the intractable IDP problem, the author calls for an increased participation of these subaltern caste groups in political decision making and policy dialogues, release of land in high security zones for the affected IDPs wherever possible, and provision of adequate incentives for remaining people to move to alternative locations arranged by the state in consultation with IDPs themselves and members of neighbouring communities where they cannot be relocated at their original sites.
\end{abstract}

\section{Keywords}

Caste, caste-blindness, ethnicity, nationalism, social class, IDPs, Panchamars, Sri Lanka

'Department of Sociology, University of Peradeniya, Peradeniya, Sri Lanka

E-mail: kalingatudorsilva@gmail.com 


\section{Introduction}

In caste-divided societies development of nationalism may be hampered because 'regardless of the actual inequality and exploitation that may prevail ....... nation is always conceived as a deep horizontal comradeship' (Anderson, 1983, p. 50). ${ }^{1}$ So in theory, caste and nation as well as casteism and nationalism are antagonistic to each other even though in reality they may coexist in various ways. While casteism privileges the hereditary caste order in ways that legitimise ranking of castes and unequal relations among castes, nationalist imagination can undermine caste loyalties and caste-based distinctions and disparities as it calls for the formation of a deep horizontal comradeship and a resulting sense of overall equality overriding hereditary ranking. Anderson was clear that nation is an imagined community that contradicts the actual inequalities in terms of class, caste, and gender. He further asserted that " "u"ltimately it is this fraternity that makes it possible, over the past two centuries, for so many millions of people, not so much to kill, as willingly to die for such limited imagining' (Anderson, 1983, p. 50). This indicates that in spite of it being a sheer imagination, nationalism is a powerful force that actually drives the politics of those converted to nationalist thinking.

In the light of the anti-colonial nationalist struggle in India, Partha Chatterjee (1986) contested the view that nation is a purely imagined community. In Nation and its fragments (1993) Chatterjee argued that nation as well as its fragments, including caste formations, are sites of struggles against colonial as well as other forms of oppression. He too, however, recognised that nationalist struggles and caste struggles operate at different levels with caste and religion as the core of the private domain outside the sphere of influence of colonial intervention per se. In other words, under the influence of Mahatma Gandhi Indian nationalism tended to safeguard caste hierarchy against colonial incursions and spiritually refine it as a form of organic solidarity devoid of exploitation, thereby contributing to human progress and mutual concern rather than rejecting it altogether as an oppressive structure. In this formulation, nationalism and caste need not be antagonistic to each other in so far as the Hindu nation encompasses castes as interdependent units needed by each other as a matter of mutual co-existence and survival. This is, of course, a view contested by Dr. Babasaheb Ambedkar, who rejected both colonialism and oppressive caste structures recognising them as harmful to liberation and human welfare. He clearly wanted to ensure that the Indian nation state had inbuilt mechanisms to eliminate or at least curtail caste inequality.

As a populist political philosophy, nationalism can also produce a utopian notion of a classless or casteless society which is an ideal that serves to hide rather than recognise existing inequalities and, thereby, silence any public discourse on class or caste inequalities. This is because nationalism seeks to both homogenise and equalise society in the name of a unified nation without actually confronting structural inequalities in society. In caste societies this can lead to what is called 'caste-blindness' in public policies. 'Caste blindness' can be defined as a deliberate neglect of caste discrimination in public policy; such policies being driven by the privileged layer of society who do not recognise or deliberately disregard caste discrimination simply because they benefit from and identify with hereditary privileges generated by the system. This is exactly what Dr. Ambedkar wanted to avoid and what prompted him to legislate against caste discrimination and go in for reservations in order to remedy the historical legacy of inequities. The term 'caste blindness' was first used in an 
assessment of tsunamic response in Tamil Nadu, India where it was argued that 'casteblindness' in tsunami response actually increased the vulnerability of tsunami-victims, many of whom were from a Dalit background. 'The government and NGOs were very slow to react to the caste discrimination, and in many cases have not yet acted to ensure equality of relief for all victims of the disaster. Many prefer to pretend there is no caste discrimination, and simply give their assistance to the fishermen because it is easy and provides good publicity.' (Gill, 2006, p. 16).

Against this background, this paper examines how rival Sinhala and Tamil nationalisms in Sri Lanka have contributed to 'caste blindness' while responding to the problem of long-term internally displaced people (IDPs) in Jaffna Peninsula several years after the end of war between the Government of Sri Lanka and the Liberation Tigers of Tamil Eelam (LTTE). Even though the war in northern and eastern Sri Lanka displaced all civilians irrespective of caste and class, the privileged layer of society managed to escape the worst of war impacts by moving out of the war-affected areas and to safer destinations in Sri Lanka and abroad. Many of those internally displaced by the war have been resettled by the state in their original villages or alternative sites. Others have moved elsewhere on their own. The last groups of IDP, however, continue to remain in IDP camps or live with their relatives many years after the war ended. Most of them happen to be from Panchamar caste backgrounds, elaborated later in this essay. The research question is why this particular segment of Jaffna society remains IDP years after the end of the war while everybody else has moved on to become a settled population regardless of whatever limitations they experience in the post-war era. The argument being developed in this essay is that this remaining group of IDP is a collateral victim of discrimination based on caste, class, and ethnicity with casteblind policies of the State and Tamil political leadership in particular, contributing to their prolonged displacement and inability to achieve their resettlement and postwar recovery. The historical and structural context of this continuing IDP problem is explored through an analysis of the caste structure in Jaffna society, history of caste struggles, and the impact of nationalist struggles on promoting caste blindness and enhancing the vulnerability of those at the bottom of the caste hierarchy.

As for the methodology employed, the paper primarily relies on available literature and secondary data supplemented by rapid ethnographic research in a selected IDP camp and a resettlement in the Jaffna peninsula. Using available secondary data with government agencies a quantitative profile of remaining IDPs is provided. As the caste identities of the remaining IDPs are not available with the relevant government authorities, key informant interviews were conducted with knowledgeable persons within and outside the communities to establish caste identities of the remaining IDP in different locations. Focus Group Discussions (FGDs) were conducted in an IDP camp and a new settlement in order to understand the reasons why the people have failed to move out of IDP camps in spite of the pathetic living conditions, stigma associated with life in IDP camps (muham) and the declared state policy of facilitating the resettlement of all war-affected people and restoring their rights including land rights, and identify the difficulties experienced by former IDP when they moved into new neighbourhoods because of their caste backgrounds. Key informant interviews with the officials in the relevant government and non-government agencies were conducted in order to explore how they recognise and interpret the current situation as a development problem and a social welfare issue. 


\section{Caste Research in Jaffna Society}

Partly because of its proximity to South India, heavy Saivite Hindu presence, and relative isolation from the rest of Sri Lanka, Jaffna has been an important site of caste research in Sri Lanka during the period 1950 to 1970. Michael Bank (1960) and Kenneth David (1976) conducted ethnographic research in selected villages with a view to understanding the structure of inter-caste relations within a structural functional framework. They both pointed to the importance of the Vellalar caste as the dominant caste in Jaffna society and as the main recipient of services by other castes in the local areas. Further, their studies revealed the religious foundation of the Hindu caste system and how religiously sanctioned notions of purity and pollution guided the hierarchy, inter-caste relations, and positioning within the religious belief system and rituals. The picture presented was a fairly harmonious model of inter-caste relations that recognised hereditary inequalities and differential dignity and honour but operated within a patron-client or allegiance framework.

Some theoretically grounded social science research on caste in Jaffna society was implemented in the subsequent decades. These included studies by Pfaffenberger (1981, 1982, 1990, 1994), Perinbanayagam (1982) and Hellmann-Rajanayakam, (1994a, 1994b). Also influenced by Louis Dumont's structuralist rendering of Hindu caste system in India, the work by Perinbanayagam (1982) and early work by Pfaffenberger (1981 and 1982), reinforced the religious and cultural foundation of caste in Jaffna with religious ideas as well as Ayurveda notions underpinning the caste system at the ideological level. Using earlier historical research by Arasaratnam (1978, 1982), Pfaffnberger (1990) found that the caste structure in Jaffna had been mediated by the establishment of tobacco farming in the Dutch period under the leadership of Vellalar commercial farmers with the backing of the colonial regime. Further he noted that the contemporary Jaffna caste system was grounded in unequal power relations rather than in Hindu belief system per se.

On the surface, one sees a 'premodern' caste system and an 'ancient' temple tradition in conflict with "modern" values and social change. Looking beneath the surface, however, one finds that this 'premodern' caste system is actually a grotesque relic of a colonial plantation economy, a fundamentally unstable system that could be maintained only by the regular application of force. (Pfaffenberger, 1990, p. 93)

The early signs of rupture in the caste system were evident in the temple entry struggles by Panchamars in the 1960s analyzed in detail by Pfaffenberger (1990). How caste related to the Tamil nationalist struggle of the LTTE was examined by HellmannRajanayakam (1993). Slowly but surely these studies also suggested that a purely cultural explanation of caste was problematic and a more nuanced understanding of the interplay between economic and political structures and the caste hierarchy was necessary in light of emerging developments in Jaffna society.

With the unfolding of the Tamil nationalist struggle, caste research was discouraged if not altogether suppressed in the 1990s. This is because certain militant advocates of the Tamil nationalist struggle saw caste as a divisive force that could potentially undermine the Tamil nationalist struggle against the Sinhala state. Cheran, who wrote about Tamil nationalism, for instance, noted the following: 
There has been a general reluctance to discuss caste issues in public. The tendency is to assert that caste was a thing of the past and Tamil Eelam will be caste-free. Any open discussion on caste is seen as bringing the old divisiveness back and therefore not healthy for the Tamil liberation struggle. On the other hand, there is a tendency among western scholars to view Tamil nationalism and the rise of the Tigers purely as a caste phenomenon. These two extremes do not reflect the complex relationship and changing caste-nation interactions among Tamils. (Cheran, 2001, p.7)

In spite of this censorship on caste as a subject of research three seminal publications on caste in Jaffna society came up during and after the war. The first is Ritual and recovery in post-conflict Sri Lanka by Jane Derges, a British anthropologist who did ethnographic research in Jaffna as part of her doctoral research. Even though caste was not the primary subject matter of this study, it pointed to the emergence of body piercing ritual of thukkukavadi among Hindu devotees in post-war Sri Lanka as a ritualistic assertion of a new Tamil Hindu identity crosscutting caste and other divisions (2013). The two other studies are by local scholars who directly encountered the censorship on caste within Jaffna society but managed to strategically overcome it by refocusing their studies. In her doctoral research on Caste and nation building: constructing Vellalar identity in Jaffna, Bahirathy Jeeweshwara Räsänen (2015) demonstrated how early rendering of Tamil nationalism from the 1950s onwards was mediated by Vellalar leadership in ways that legitimised their position in Tamil society and politics and how this was transformed by the LTTE led by middle-level castes in the Hindu caste hierarchy in ways that problematise the Vellalar leadership and legitimise the LTTE struggle against Sinhala domination on the one hand and Vellalar monopoly in Tamil society on the other. Focusing specifically on the subaltern layer of Jaffna society, Thanges and Silva (2009) identified Panchamars as lasting and continuing victims of the war as some of them continued to be stuck in IDP camps following the end of war while the other Tamil IDP have long been resettled with government and donor support. Continuing this line of research, the current paper further examines how caste-blind policies of the state and nationalist politics in general have aggravated the vulnerability and existential insecurities of oppressed-caste IDP many years after the end of war.

\section{Caste Structure in Jaffna Peninsula}

The caste structure in Jaffna Peninsula evolved over a long period of time with shifts caused by the establishment of commercial agriculture in the Peninsula during the Dutch colonial regime solidifying the caste hierarchy in important ways. More recently the war and related population movements have had a major impact on caste composition in the region. As no caste censuses have been conducted by the government or any other agency, no reliable information about the caste composition in the region is currently available. Bank's (1960) original estimate as amended by Pfaffenberger (1982) and Sivathamby (1995) can be used as a baseline for the analysis. 
Table I. Castes in Jaffna Peninsula, 1982

\begin{tabular}{|c|c|c|c|}
\hline $\begin{array}{l}\text { Caste Name in } \\
\text { Tamil }\end{array}$ & English Rendering & Caste occupation & $\begin{array}{l}\text { As a \% of total } \\
\text { Tamil population }\end{array}$ \\
\hline Piraman & Brahman & Temple Priest & 0.7 \\
\hline Saiva Kurukkal & Saiva Priest & $\begin{array}{l}\text { Priests in Non-Brahman } \\
\text { temples }\end{array}$ & \\
\hline Vellalar & Land owning caste & Landlord, farmer & 50 \\
\hline Pantaram & Garland maker & Temple helper & \\
\hline Sipacari & Craftsman & Temple sculptor & \\
\hline Koviar & & Domestic worker for Vellalar & 7 \\
\hline Thattar & & Goldsmith & 0.6 \\
\hline Karaiyar & & Deep sea fisherman & 10 \\
\hline Thachchar & Carpenter & Wood work, Roof maker & 2 \\
\hline Kollar & Iron work & Blacksmith & \\
\hline Nattuvar & Musician & Auspicious music & \\
\hline Kalkular & Weaver & & \\
\hline Cantar & Oil maker & Sesame oil maker & \\
\hline Kukkuvar & Potter & Potter & \\
\hline Mukkuvar & & Lagoon fisher & \\
\hline PANCHAMAR & CATEGORY & & \\
\hline Vannar & Dhoby & & 1.5 \\
\hline Ampattar & Barber & & 0.9 \\
\hline Pallar & Manual worker & Bonded labour & 9 \\
\hline Nalavar & Toddy tapper & Toddy tapper and farm worker & 9 \\
\hline Paraiyar & Drummer & Funeral Drummer & 2.7 \\
\hline
\end{tabular}

Source: Adapted from Thanges and Silva (2009).

Note: Gaps in demographic data are due to non-recognition of the relevant caste groups in the original estimate. The size of the relevant case groups, however, may be too small to alter the overall pattern indicated by the estimates given.

The caste structure of Jaffna society consists of roughly twenty castes with Vellalar caste historically accounting for nearly 50 percent of the total Tamil population in the region as the undisputed dominant caste controlling land ownership, agriculture, leadership positions and white collar employment in colonial and post-colonial settings (Table 1). Brahmins and Saiva Kurukkals are ritually superior to Vellalars but they are often employed by Vellalar temple trustees making them economically subordinate to the dominant caste. With the exception of Karaiyars, Mukkuvars, and possibly Kukkuvars who were largely self-employed and economically independent, all the other castes historically served hereditary patron families of the dominant caste (Refer Table 1). The Panchamar castes were identical to dalits in the Indian context as they were considered untouchable and outside the touchable caste category and hence the fifth caste following the Indian model. Except in a few instances, the word 'dalit,' however, was not used for self-identification or as an analytical category in caste research in Jaffna or anywhere else in Sri Lanka. In addition to the term Panchamar, the terms 'depressed castes,' 'depressed classes' or 'minority Tamils' have been used to refer to them in the literature and mass media. 
One important feature of the caste system in Jaffna that has so far received inadequate attention is the close correspondence between caste and social class in Jaffna society. Vellalars are not only the dominant caste in society but also the social and political elite in society with property ownership, high levels of education, professional employment, control over temples, and Tamil politics prior to and since the end of the war. They also had a tight grip over the Panchamars in terms of securing their hereditary caste services, including ritual duties and agricultural labour in farming activities. As elaborated by Chatterjee (1993) in respect of West Bengal the shape of class relations in Jaffna society was clearly overlaid by caste identities and responsibilities giving them the character of bonded labour particularly in the farm sector. This also indicates that the effort by Louis Dumont to reduce caste to hierarchy identified as a purely ritual order determined by the dichotomy between purity and pollution is problematic in Jaffna society at least from eighteenth century onwards. Jaffna caste system also resembles graded inequality characterised by Thorat and Madheswaran in their work on India (2018) in the sense that poverty and lack of assets are characteristic of the lower end of the caste hierarchy.

\section{History of Caste Struggles}

The history of caste struggles in Jaffna actually started long before caste struggles became a regular feature even in Indian society. Thus, instead of treating the caste system as sacred and immutable, rumblings against caste in Jaffna started way back in the 1920s. Why they did not progress in the way they did in India itself is important from the angle of a comparative analysis of caste dynamics in South Asia. Another important issue is how caste struggles in Jaffna gradually gave way to a violent Tamil ethno-nationalist struggle with ethnicity gradually replacing caste as the primary basis of social identity and the platform for social and political agitations. As these two developments are centrally important for the argument of this paper, the researchers focuses on them in the current and the following section.

Ravikumar (2002), a political actor representing the oppressed caste groups in Jaffna, has documented the popular history of Dalit (Panchamar) struggles in Jaffna society, he being one of the few commentators opting to identify the Panchamars in Jaffna as Dalits. Using the famous chauvinistic quote from Arumuga Navalar, the nineteenth century founder of Tamil Hindu nationalism that 'Parai drum, ${ }^{2}$ women and Panchamar are all born to get beaten,' Ravikumar argued that casteism is built into Tamil nationalism from its very beginning.

Long before the Tamil nationalism got established in Jaffna in the 1940s, caste struggles had started with the formation of the Forum for Depressed Class Tamil Labourers in 1927. In the following year this forum launched an agitation for 'equality in seating, equality in eating' in protest against caste discrimination in schools where Dalit children were barred from sitting and eating with other children. Two years of continuous struggle led to an administrative order on grantaided schools that low-caste children should be allowed to sit on benches side by side with other children. In retaliation, caste Hindu Tamils burnt down 13 schools that implemented the new regulations. And by way of political follow-up, the Vellalar elite petitioned the government in 1930 to withdraw the equal-seating directive, which, however, was not successful. 
The next important milestone in caste struggles in Sri Lanka was grating of universal franchise by the Donoughmore Commission in 1931. Under the leadership of Vellalar politicians like S. Natesan, the caste Hindus protested against the granting of franchise to Panchamars. According to Ravikumar (2002, p.3 ) 'caste Hindus were ready to give up their own voting rights to prevent the dalits from getting theirs.' As they could not obstruct the granting of franchise to the Panchamars, the caste Hindus imposed a new set of prohibitions on the oppressed groups particularly targeting women and children in order to emphasise their subordination to Vellalars. These retaliations, however, were short-lived and they did not deter Dalit activism. The Conference of Oppressed Tamils in Jaffna was held in August 1943. It resulted in the formation of the Northern Sri Lankan Minority Tamil Mahasabha for the purpose of campaigning against caste injustices.

When Soulbury Commission conducted public hearings about constitutional reform in Sri Lanka from December 1944 to April 1945, the Northern Sri Lankan Minority Tamil Mahasabha made representation independently of the Tamil Congress led by G. G. Ponnambalam representing the Vellalar interests. The Mahasabha, however, could not secure separate concessions for them in the new constitution due to constant pressure from the Tamil Congress for legal provisions for Tamil rights in general. During the first national elections held in independent Sri Lanka in 1947 the Mahasabha opted to support the Communist Party instead of the Tamil Congress which refused to field any Panchamar candidates in their party nominations. This alignment with the Communist Party at the national level was interesting in light of the correspondence between working class and Panchamar interests in Jaffna society. A Tamil political party willing to accommodate Panchamar interests, however, was formed as Tamil Arasu Party in the 1950s. As this party agreed to promote Panchamar candidates as well, a section of Mahasabha joined the Tamil Arasu Party while another section continued to support the Communist Party during this period. This political split within the Panchamar community served to weaken their struggle against the caste system. The grievances among Panchamars, however, remained high well into the next decade. The passing of Prevention of Social Disabilities Act of 1957 was an important achievement for minority Tamils in this period. This Act identified any prohibitions or restrictions imposed by the dominant caste against traditionally oppressed castes in matters such as dress code, education, admission to public places, and use of public facilities as illegal. Framed and formulated by Sinhala political parties in the South with the intention of dividing up the Tamils and weakening their demand for federalism at the time, this Act did not have much effect in reality except for its rhetorical value.

The temple entry struggles by Pallar and Nalavar activists in 1968 targeting the famous Maviddapuram Hindu temple controlled by Brahmins was an important caste struggle in Jaffna. As in other Hindu temples controlled by Vellalars and their priests, Pallars and Nalavars were not allowed to enter Maviddapuram temple claiming that their entry would pollute its sacred space. Led by a member of the Communist Party and reportedly backed by Sinhala politicians from the South, activists from these castes considered it a violation of their rights and demanded that they be allowed to enter the temple. This in turn produced retaliatory physical attacks on the protestors by Vellalar and Koviar thugs leading to a cycle of violent 
attacks and counter attacks in a number of places in Jaffna. The Federal Party led by the dominant caste tried to diffuse the situation by publicising symbolic gestures of opening the gates of some temples for representatives of the two oppressed castes but no effort was made to actually resolve the issue by bringing about a negotiated settlement between the rival parties.

In his detailed study of these agitations, Pfaffenberger (1990) noted that the temple entry struggles produced an important turning point in Tamil politics in Sri Lanka in general. It was a turning point in the sense that it marked a transition from divisive caste struggles within Jaffna society itself to the ethnic politics of a unified Tamil struggle against the Sinhala-controlled state in southern Sri Lanka. According to Pfaffenberger, Tamil political leadership sought to unify all Sri Lankan Tamils within the framework of a 'defensive' Tamil nationalism in order to avert volatile internal struggles triggered by internecine caste struggles. In Pfaffenberger's (1990, p. 93) own words:

In creating a politics of electoral unity, Tamil politicians had to navigate a contradictory and dangerous mine field. They succeeded, but only by deflecting the Tamil community's attention away from the peninsula and toward the broken promises and discriminatory actions of the Sinhalesedominated government. This was a politics that tiptoed quietly away from issues that would divide Tamils; it created electoral unity around the program of defensive nationalism but without really devoting any attention to the fundamental issues of social and economic inequality within the Tamil community itself.

What Pfaffenberger charaterised as 'defensive Tamil nationalism' served not so much to remedy caste resentments as to deflect them to an external enemy posing a greater threat. This helped the protagonists of defensive nationalism to direct their violence outward and attribute all their problems to hostilities by an ethnic other. This in turn suggests that as an ideology nationalism serves to de-emphasise internal problems and over emphasise external threats stemming from a perceived ethnic other. In confronting the problem of suffering and existential insecurities, nationalisms have a tendency to soft-peddle certain issues, suppress others and project the ethnic other as the sole explanation of one's problems.

\section{Eelam Struggle and the Problem of Caste in Jaffna Society}

The twin objectives of the Eelam struggle were to achieve autonomy from the Sinhala state and establish a casteless society in the Eelam state. Tamil nationalism's aim of abolishing caste is not new. Way back in 1976 the Tamil United Liberation Front (TULF) adopted the goal of eliminating caste as part of the famous Vadukkoddai Resolution (Rasanen, 2015, p. 164). Elaborating the political agenda of the LTTE, Hellmann-Rajanayagam (1993) argued that the LTTE fought two separate battles, one against the external enemy, the Sinhala state and other against the caste system in Jaffna society. The caste struggle, however, was delicately poised as the LTTE did not want to antagonise the Vellalars comprising the largest and the dominant caste in Jaffna and pursue a divisive policy that would weaken the Tamil liberation struggle against the Sinhala state. With the formation of LTTE, leadership of Tamil politics shifted from Vellalar elite to Karaiyar and middle level castes in Jaffna society. In response there was 
a selective outmigration of Vellalars during the war altering the existing demographic profile in the peninsula (Silva, 2018). The percentage of Vellalars in the population perhaps dropped from 50 to 30 and there was a proportionate increase in the nonVellalars including the Panchamars up to about 30 percent of the population by 2005 . The LTTE cadres came from all castes and diverse social class backgrounds but the Panchamars perhaps made up the bulk of the cadres as noted by Ravikumar in 2002. The approach of the LTTE was not to openly talk about caste or address grievances openly. Instead the LTTE imposed strict penalties including imprisonment for those practising caste discrimination. Any discussion on caste in day-to-day conversation, including mentioning of caste identities of people, was completely prohibited. The assumption was that this would lead to a gradual abandonment of caste as a principle of social organisation in the Eelam state (Thanges, 2015).

The LTTE, however, did not have a clearly formulated policy for dealing with caste. Inter-caste marriages were encouraged and practised by the LTTE leadership as a model for the society at large. The LTTE did not want to introduce any radical measures for confronting the caste order perhaps due to the fear of losing support from caste Hindus in the process. On the other hand, several pragmatic interventions were made in order to accommodate minority Tamil interests. They may also be seen as a way of adjusting to the changing caste demography and to facilitate recruitment drives in the wake of outmigration, population displacement, and overall depopulation of certain regions. The author summarises these pragmatic interventions as follows:

1. Some of the key leaders were from the bottom layer of society. For instance, Thamil Chelvam from barber caste rose to the top level in the political wing of the LTTE .

2. As a pragmatic intervention based on current demographic realities, the LTTE recruitment drive targeted some Panchamar villages where poverty, lack of options, and feeling of social exclusion encouraged the youth to join the movement.

3. The LTTE cadres who sacrificed their lives for the struggle became war heroes (maveerar) irrespective of their caste background and the maveerar families were entitled to special welfare assistance from the LTTE.

4. Some of the land and houses abandoned by the caste Hindus who moved out during the war were distributed among maveerar families including those from Panchamar background.

5. The LTTE used certain Panchamar communities as their bases and places of refuge when needed for their political activities and even intelligence operations. This of course made these communities vulnerable for surveillance and arrests by security forces. However, the LTTE also undertook special efforts to help stabilise these communities and provide services when necessary.

6. In the LTTE camps members of different castes intermingled with each other without any restrictions. They often addressed each other using kinship terms with LTTE supremo Prabaharan usually referred to as Annai (older brother). In the camps they ate together and worked together disregarding caste differences.

7. The LTTE encouraged certain castes like barbers and washers to stop visiting high caste homes for their services and to establish and provide their services through barber saloons and laundries respectively in an effort to convert them from hereditary caste services to commercial transactions with no caste identities and hereditary modes of transactions implicated. 
8. The dead martyrs were buried in LTTE cemeteries side by side irrespective of their caste which went against the customary practice of separate cemeteries for different castes.

These measures indicate that the LTTE was 'caste sensitive' rather than 'caste blind.' In spite of these remedial measures, the policy of the LTTE was to not recognise caste for any official purposes of the organization. While these 'unofficial' interventions were in the nature of affirmative action for the benefit of those at the bottom of the caste hierarchy, there was no officially accepted procedure for identifying victims of caste discrimination or perpetrators of caste injustices. These interventions were by no means radical in terms of altering the existing caste hierarchy or tipping the power balance in favour of those at the lower end of the caste hierarchy. They were, however, seen with suspicion by the Vellalars and interpreted as evidence of the LTTE favouring the underdogs as evident in an ethnographic study by Rasanen on a Vellalar community (2015). She recognised an important distinction between a more hegemonic Tamil nationalism mediated by the conservative Vellalars since the 1940s and the LTTE mediated Tamil nationalism designed to create opportunities for the subordinate caste groups evolving in the 1990s. Capturing the mainstream Vellalar view about the LTTE, she reported the following (2015, p.166).

In the local elite understanding, the Vellalah who mastered the pen were replaced by those who mastered martial skills - the fishing castes and depressed castes. It left a feeling of animosity among Vellalah on the whole; it was particularly intense among local and national Vellalah elites who were educated and disempowered socially and politically.

On the whole the LTTE assumed that, over the years, caste would have a natural death in Tamil eelam because of intermingling of IDP from different castes in IDP camps, officially imposed public silence about caste in the communities, strategic but subterranean interventions by the LTTE targeting victims of caste discrimination, and increase in inter-caste marriages due to social necessities, and the hidden LTTE policy of encouraging such marriages.

\section{Caste Background and the Problems of Remaining IDP in Jaffna Peninsula}

The war between the Government of Sri Lanka (GOSL) and the LTTE from 1983 to 2009 uprooted nearly all Tamil inhabitants in the Jaffna Peninsula irrespective of their social class, caste and gender. The total number displaced persons by the brutal war is estimated to be around 1.5 million. Some 750,000 people moved to foreign destinations in Europe, North America, and elsewhere as refugees or as legal migrants. The remaining 750,000 were internally displaced within Sri Lanka in IDP camps, among relatives of the displaced, and in various other arrangements. Ten years after the end of the war, most of the IDP resulting from the war had been resettled by the GOSL in either their original villages or in new settlements. The GOSL has 
declared its policy of resettlement of IDP successful in terms of housing, infrastructure development, livelihood restoration, recovery and reintegration of IDP. However, as of early 2016, the resettlement of IDP remained an unfinished business and the last set of IDP yet to be resettled remained an intractable problem as they appeared to be collateral victims of the war as well as continuing processes of ethnic, class, and caste oppression.

As of January 2016, approximately 38,000 people (11,000 families) were identified by the state as remaining IDP in Jaffna peninsula. The veritable 'wretched of the earth' among them were some 3,970 war-displaced persons (1,100 families) who lived in a total of 31 IDP camps located across six administrative divisions in the Jaffna Peninsula. Many of these IDP have been living in the camps ('welfare centres' in government terminology) for well over two decades and others were born in these camps. The relief and subsidies provided to these IDP by the state and NGOs was discontinued in 2011 but that did not encourage them to move out. The UN High Commissioner for Human Rights, Zeid Raad Al Hussain, who visited selected IDP camps in Jaffna in February 2016, referred to them as a 'lingering sore' in post-war recovery in Sri Lanka (Sunday Times February 26, 2016).

Prior research by Thanges and Silva (2009), Thanges (2013, 2015) and Rasanen (2015) found that many of these long term IDP belong to the Panchamar category. While the war displaced most Tamil inhabitants in the Jaffna Peninsula irrespective of their caste and class, the largely overlapping categories of upper class and the high castes in Jaffna (see Pfaffenberger 1982, 1990) were able to move out to safety from the IDP camps using their social networks, market skills and financial resources at their disposal. On the other hand, the displacement of depressed Panchmars was prolonged due to a complex web of factors. The post-war IDP count in Jaffna presents a few surprises (Refer Table 2). Most importantly among these long-term IDP still living in the camps the Vellalars, who continue to be largest caste in Jaffna society in spite of a significant drop in their numbers due to selective outmigration during the war, are conspicuous by their absence. While there still may be some Vellalar IDP living among their relatives and not in the camps, that itself shows that camps have become caste uniform over the years with a sorting out of the population along caste lines. Thus among the remaining IDP in Jaffna Peninsula as of January 2016, two Panchamar castes, namely Nalavar (toddy tappers and fishers) and Pallar (manual workers and hereditary farm workers for Vellalar landlords) comprise over seventy five per cent of the remaining IDP leaving aside IDP camps with people from two different castes. In four of the six Divisional Secretary Divisions (DSDs) where IDP camps continued to exist in 2016, all the remaining IDPs belonged to these two subaltern caste groups. A total of four IDP camps had mixed populations drawn from Nalavar and Pallar castes. In Point Pedro and Karaveddy Divisional Secretary Divisions most remaining IDP belonged to Karaiyar caste, considered to be a middle level caste in Jaffna society. In one IDP camp in Point Pedro, Karaiyar and Pallar lived side by side. Irrespective of their caste background, most long-term IDP had been displaced from the fertile northern coastal stretch in the Peninsular also with some of the best fishing grounds in the country acquired by the military to establish high security zones (HSZs) for strategic security considerations. The caste configurations among the surviving IDP reflect a spatial segregation along caste lines as well as a clear tendency among IDP to stay with fellow caste members. 
Table 2. Number of People in IDP Camps in the Jaffna District by Caste Background of IDP and by DS Division, January 2016

\begin{tabular}{|l|c|c|c|c|c|c|}
\hline DSD & Pallar & Nalavar & $\begin{array}{c}\text { Pallar and } \\
\text { Nalavar }\end{array}$ & Karaiyar & $\begin{array}{c}\text { Pallar and } \\
\text { Karaiyar }\end{array}$ & Total \\
\hline Telippalai & 30 & $\mathrm{I}, 05 \mathrm{I}$ & 60 & 0 & 0 & $\mathrm{I}, \mathrm{I4I}$ \\
\hline Sandilipai & 0 & 85 & 0 & 0 & 0 & 85 \\
\hline Uduvil & 39 & $\mathrm{I}, \mathrm{II}$ & 212 & 0 & 0 & $\mathrm{I}, 367$ \\
\hline Koapai & 650 & 0 & 0 & 0 & 0 & 650 \\
\hline $\begin{array}{l}\text { Point Pedro and } \\
\text { Karaveddy }\end{array}$ & 0 & 0 & 9 & 559 & $15 \mathrm{I}$ & 710 \\
\hline Total & 719 & 2,252 & 272 & 559 & $15 \mathrm{I}$ & 3,953 \\
\hline
\end{tabular}

Source: Jaffna District Secretariat, Resettlement Division

Note: IDP numbers were secured from the resettlement division of the Jaffna Kachcheri. Caste identities were established through key informant interviews and cross checking with different KIs.

The continuation of caste-based residential pattern among the long-term IDP points to the failure of the long history of caste struggles as also the failure of the LTTE approach of subterranean interventions to dissolve caste ties in Jaffna society. They also indicate that ethnically filtered and 'caste blind' policies and politics of Sinhala and Tamil political parties may fail to resolve the long-term IDP problem in Jaffna society satisfactorily. Even though the LTTE sought to dissolve caste identities in favour of a unified Tamil eelam, caste identities are resurfacing and new inter-caste formations emerging particularly among subaltern groups in postwar Jaffna Peninsula.

In one such mobilisation, some leaders of IDP communities established a Welfare Centres Management Committee (WCMC) representing the interests of all IDP camps vis-à-vis the government in 2015. Led by a dynamic person named Anthony Quinn, this organisation sought to unify the residents of all IDP camps in a broad-based alliance to negotiate with the government authorities regarding their problems. While this was an IDP organisation representing the needs and grievances of long-term IDP in Jaffna Peninsula, because of the caste backgrounds of these victims of the war and caste oppression in society it was also a mobilization of subaltern castes facing new challenges in postwar Jaffna society. As the leader of Sapapathipillai camp identified with the Nalavar caste, Anthony Quinn himself came from an ethnically and religiously mixed Karaiyar-Nalavar and Hindu-Catholic background, he was able to bring all IDP camps representing Nalavars and Pallars in Tellipalai, Sandilipai, Uuduvil, and Kopai divisions under the umbrella of this new organisation. However, Karaiyar IDP camps in Point Pedro and Karveddy refused to join his organisation claiming that the new alliance did not represent their interests. According to the leaders of WCMC, this action motivated largely by caste considerations of Karaiyar IDP in Velvetithurai, seen as a Karaiyar stronghold and their refusal to treat lower caste IDP as their equals let alone partners in a common struggle, served to dampen their struggle for winning their rights as IDP. While Nalavar and Pallar IDP coming together for joint action may be seen as an important new development in the light of their shared plight, the refusal of Karaiyar IDP to join WCMC points to the continuing social gap between Panchamars and those above them in the caste hierarchy even when they have a common interest as long-term IDP. 
The Government has not been able to resettle these long-term IDP due to a combination of factors, including the forcible acquisition of their land by the predominantly Sinhalese military for establishing high security zones (HSZs) and the refusal by the security forces to release the acquired land for IDP resettlement on the grounds of security for military installations, complete landlessness of some of the IDPs, and the dogged refusal of many to move to alternative sites and accept the package of incentives proposed by the government. This had resulted in a deadlock in government plans to complete the resettlement process and proceed with the post-war recovery in Sri Lanka.

\section{Why Have the Long-term IDP Failed to Move Out of IDP Camps?}

If the war affected everyone in Jaffna society irrespective of caste, class and gender, how do we explain the particular social and demographic configuration in the remaining IDP camp population in Jaffna Peninsula? One possible explanation is that the war did not impact the civilian population indiscriminately; the rich and the powerful were able to move to safety using their contacts and economic and human resources leaving behind the poorer and the underprivileged to bear the brunt of the 25-years long armed conflict (Silva 2017). While this explanation has considerable merit in clarifying the current demographic profile in Jaffna Peninsula (Silva 2018), it completely takes away the agency of the socially marginalised and their possible engagement in violent and non-violent collective action in order to advance their common interests and assert their rights. Also, it indicates the failure of both caste-blind policies of the State and nationalist politics in general, and the caste-sensitive interventions by the LTTE at the subterranean level to create a level playing field in postwar Sri Lanka.

The failure of the Sri Lankan state to bring a closure to the IDP problem in Jaffna ten years after its military victory over the LTTE in spite of the efforts by the new political regime which emerged in the centre in 2015, to release some of the land under HSZs for their original owners can be attributed to a complex set of factors, including divergent pressures on the Sri Lankan State, the nature of centre-periphery relations and the limited influence the IDPs have over central and provincial governments. The disproportionate ${ }^{3}$ Panchamar presence in the remaining IDP camps must be seen as a further complication resulting from the continuing barriers and exclusions they encounter in joining the social mainstream in post-war scenario. These barriers perhaps stemmed from their greater vulnerability to long-term displacement during the war, their specific role and engagement in the armed struggle, over dependence on the LTTE as their sole benefactor during the war and helplessness they experience following the demise of LTTE, lack of representation within the political forces in post-war Sri Lanka and their inherited disadvantages in the local land market.

First, the subaltern caste groups with fragile land rights in interstitial spaces in-between Vellallar and Karaiyar settlements were probably more vulnerable to displacement during the war also because the Sri Lankan security forces often acquired these spaces to establish high security zones. The lowest castes owned limited extents of land, compelling them to work for Vellalar landlords who gave them house sites on edges of their land free of charge (Pfaffenberger 1982, Räsänen 2015). Further the Thesavalamai customary law outlawed the transfer of land from Vellalars to non-Vellalars, interfering with the establishment of a free land market. As is well 
documented in the literature on disasters (Silva 2015, Gill 2007), occupants of these marginal spaces are more vulnerable to disasters, natural or human-made.

Second, as noted earlier, the Panchamar castes often constituted the foot soldiers of the LTTE. The subterranean interventions of LTTE had the effect of consolidating Panchamar communities with the result that they may have been the targets of antiLTTE operations during and after the war. These communities were more likely to stay together even after the war ended. Unlike the richer Vellalars who were displaced and who used their own resources and contacts in order to move to safety out of the war zone, with limited resources at their disposal the lowest castes relied on their own communities in order to cope with their problems. In some cases, the LTTE land grants to these communities became untenable after the LTTE regime ended. For instance, the lands on which the Sapapathy, Kanaki and Periya Mathadevi camps in Uduvil DSD were located were reportedly cotnrolled by LTTE having acquired them from the previous owners who had migrated overseas during the war. The owners, who did not demand their land when the LTTE was active, reclaimed it once the war ended thus preventing the onsite resettlement of the IDP living there even after the end of the war (Rajasingham, 2014). The limited land resources owned by the IDP were mostly in HSZs some of which was returned to the people by the security forces since 2015 on a scattered basis. Further, unlike the upper caste IDP who moved out to other areas, and overseas destinations individually using their existing social contacts, the subaltern IDP who were left behind in the camps sought to move back to their original villages as a community, perhaps as a collective means of dealing with social rejection and discrimination by the privileged castes.

Third, the Panchamar IDP had become victims of a power struggle between Tamil political parties and the GOSL. For Tamil political parties they are victims of discrimination by the Sinhala State to be showcased as victims of ethnic discrimination. In none of their campaign documents the long-term IDP are identified as Panchamars who experience multiple discrimination due to caste, class and ethnicity. On the other hand, caste blind and ethnically biased policies of the State have failed to understand the nuances of the situation. In spite of the demographic shifts in the Tamil population in the Peninsula, the non-Vellalars do not seem to have adequate representation in these parties and in elected representation in the central government, Provincial Councils and even in Pradeshiya Sabas largely controlled by Vellalar-affiliated Tamil National Alliance (TNA). In many ways the conventional Tamil political leadership in post-war Sri Lanka remains rather aloof to the needs of the underprivileged caste groups as had been the case in the pre-war era. Simultaneously, the remaining IDP camps are a useful platform for the Tamil political leadership to demonstrate to the rest of the world that the central government has failed to complete the resettlement of IDPs, demand the dismantling of high security zones in the peninsula and campaign for greater political autonomy for the minorities. On the other hand, the Sri Lankan State and the security forces are hesitant to release land in the remaining HSZs and seem to be completely unaware that the remaining HSZs prevent the bottom layer of Jaffna society from going back to their original homelands.

Finally, the Panchmar IDP do not have the resources to break the vicious cycle of poverty and displacement and move to some alternative sites on their own also due to the disadvantages they experience in the local land market heavily controlled by the Vellalar land owners. Even though the absentee Vellalar landlords had allowed some Panchamar families to occupy their vacant houses particularly in islands off 
the Peninsula, transfer of land ownership across the caste divide has been rare and considered morally unjustified by Vellalar landlords (Silva, 2017, Thanges 2015, Rasanen 2015). This is a classic example where ethnic prejudices and class and caste inequalities reinforce each other in ways that make the IDP collateral victims of multiple forms of oppression and discrimination many years after the end of war.

\section{The Living Conditions of Remaining IDP}

The remaining IDP camps in Jaffna Peninsula are characterised by poor housing, congestion, underserved conditions in relation to water and sanitation, and vulnerability to natural and social hazards, including infections.

The one or two room housing units are made of tin sheets, wooden planks and cadjan. During the hot summer there is unbearable heat inside these houses. During monsoon, roofs leak and the entire camps get flooded because of their low-lying character. The camps are overcrowded with lots of shelters occupying a limited space. For instance, in 2016 in the adjoining Sapapathy and Kannaki camps in Uduvil DSD, 932 people from 250 families were huddled together in a land area of eight acres.

The provision of water and sanitation to the IDP communities remains extremely poor. Most camps had no running water. ${ }^{4}$ There are one or two wells which often dry up during the periods of drought. The Vellalar communities in nearby villages are not willing to share their water sources, including wells, with people from the IDP camps (muham) due to continuing ideas about pollution and contamination. In one camp about 400 people shared a total of seven common toilets with one toilet being shared by nearly fifty-eight people. The long waiting time to use toilets was part of the daily routine in the IDP camps.

The dry rations issued to IDP by the Government of Sri Lanka with support from UN agencies was discontinued in 2011 reportedly due to the desire of the Rajapaksa regime at the time to impress upon the international community that the resettlement of war-induced IDP had been completed. On the other hand, the dry rations were not replaced with the state-run Samurdhi Programme targeting the poor, reportedly because they were not permanent settlers of the relevant administrative divisions. Thus the remaining IDP in the peninsula received neither the dry ration meant for IDP nor Samurdhi benefits meant for the poor. They were also disqualified from housing assistance for resettling IDP provided under World Bank and Indian Government assistance as they did not have title to any buildable land. In some ways they were double victims of 'caste blind' and exclusionary ethnic policies of the State and international donors. In a curious reflection of ethnic filters and caste blindness in many of these agencies, the complexities of the problem of remaining IDP have not surfaced in policy discussions in any of these organisations.

The educational services were poor. Some IDP camps had primary schools with minimum facilities. According to one newspaper report, for IDP children 'it was just a case of sitting in a makeshift classroom for a few hours, sometimes learning and at other times chatting.' If the IDP children wanted to go beyond primary education, they had to be transferred to better schools outside the community, where IDP children experienced a range of discrimination from fellow students and from teachers hailing from higher caste backgrounds. In spite of these obstacles, a few bright children from these communities did manage to do well in studies and enter the university system. In 
summary, most IDP children ended up with limited capabilities that merely prepared them for casual wage labour opportunities in the labour market.

For the most part, the IDP camps had become sources of cheap labour for commercial farmers and labour contractors in the surrounding areas. Having being completely displaced from self-employment as farmers or fishers, the camp residents were reduced to daily wage labour as their primary livelihood. Thus these communities were not only caste uniform but also class uniform as wage earners. The daily wage for men and women were around Rs. 1000-1200 and Rs. 500 to 600 respectively. Often, they were not entitled to any fringe benefits like free food from the employers signifying an almost irreversible end of traditional patron-client relations in the labour market. Employment was available in commercial farms, construction sites, quarrying and informal sector, food preparation and vending, and rarely in the formal sector. In many places the workers from the camps were treated badly by the employers due to their caste as well as muham background.

A new settlement called Nallinakkpuram (literally meaning 'reconciliation village') established by the Ministry of Rehabilitation headed by a UNP Tamil minister from Colombo for selection of IDP was ceremonially opened in Valikamam North DSD in December 2016 for a total of 100 IDP families recruited from a number of IDP camps in selected DSDs. This is considered a relocation since the settlement was established in vacant crown land situated close to KKS beach. The houses were built by the military with funds from the Rehabilitation Ministry. The Tamil political leadership of TNA did not like this project because of the military involvement and also because the project was resented by Vellalar settlements and a number of Hindu kovils in the area. The residents of the new settlement felt that they were not welcome in the area dominated by the Vellalar communities because of their Panchamar caste background. A primary school was newly established in Nallinakkapuram but the older children experienced some difficulty in getting admission to existing secondary schools and a common playground in a nearby village was reportedly covered by a fence in order to prevent the children from the new settlement using it.

Many of the new settlers were keen to start fishing, their traditional occupation, in the nearby sea but they were prevented from doing so as the area was considered a sacred site (punithabhumi) by trustees of nearby Hindu kovils who were essentially Vellalar. A local Tamil politician protested against the project claiming that part of the housing scheme is actually established on private land owned by his family. The new settlers were happy that they were able to get a decent house of their own, but they were complaining that they were not yet granted title to the land even though it was promised by government authorities. Further, they experienced a number of caste-based social rejections and opposition to the commencement of their traditional livelihood of fishing even though the fishing grounds are within their reach. Nallinakkapuram clearly points to the kind of difficulties that these subaltern castes encounter when they move to new areas dominated by Vellalars. Clearly the central government and military engagement were instrumental in opening this new settlement for landless IDP. However, it is quite clear that this state intervention was not informed by a sound understanding of caste dynamics affecting the remaining IDP in Jaffna society. 


\section{Conclusion}

Neither the political process guided by rival nationalisms, nor State policies shaped by ethnic filters and caste blindness help us fully understand why the IDP problem in Jaffna has persisted in the post-war era. A nuanced understanding of this problem must recognise intricate interactions among ethnicity, social class and caste in contemporary Sri Lanka society. The failure of the Sri Lanka State to satisfactorily conclude the resettlement process and end the suffering of the remaining IDP in Jaffna Peninsula indicates either its lack of understanding about the problem, or its remoteness, or lack of concern about the plight of the residual war victims. On the other hand, the Tamil electoral politics is equally insensitive and merely seeking to perpetuate the problem for its own propaganda purposes also reflecting that Panchamars are poorly represented in the political process at all levels. During their heyday, the LTTE may have empowered the Panchamars to some extent, but clearly the subterranean interventions of the LTTE failed to mobilise them in such a way that they could assert themselves so as to influence public policies that affect them. WCMC may be seen as an important initiative from the angle of mobilisation of Panchamars as war victims, victims of caste and class discrimination as well as victims of poorly informed state policies relating to the resettlement of IDP, but it has a long way to go in terms of liberating this subaltern group in Jaffna society.

\section{Policy Options Available}

The Tamil political elite has been lobbying for closure of HSZs in the Northern and Eastern Provinces, removal of military bases and progressive reduction of the military presence in these areas as a precondition for restoration of civilian life in the region. On the other hand, the government security forces have been pushing for a payment of compensation to IDP for the land lost to HSZs and providing additional support to the IDP to move to alternative sites or resettle in the existing sites. Neither party is willing to reach a compromise that would end the prolonged suffering of these last cohorts of socially marginalised IDP. Interestingly both the GOSL and the Tamil political elite purely approach the problem from an ethnic or political angle and in a 'caste blind' manner. The Tamil leadership explicitly campaigns for their resettlement in their original villages that are currently under HSZs. While closure of HSZs may be necessary in the long run, this, however, may not be a pragmatic solution for all remaining IDP as some of them reportedly do not own any land in HSZs or anywhere else. Thus, it's only a compromise solution, acceptable to IDP, GOSL and the Tamil political leadership, that can put an end to the long-term suffering of the IDP. This may be one instance, where the conventional ethnically biased and caste-blind policies pursued by the Sri Lankan State must be revisited in order to enable the remaining IDP to overcome possible discrimination they face in the land market, education system and the job markets other than casual wage labour. Their successful reintegration in the society depends not only on whether they as citizens of Sri Lanka will receive their due share of land and other assistance from the Sri Lankan welfare state, but also whether or not they will be further subjected to discrimination on the part of the society at large, including their fellow citizens in Tamil society. Empowerment of the IDP through their collective mobilisation vis-à-vis ethnic, class and caste discrimination and enhancing their collective capacity to identify, resist and overcome such discrimination may be a prerequisite for enabling them to join the social mainstream. 
On the whole, this study illustrates how the war affected people differently depending on their particular social positioning in respect of ethnicity, social class, caste and gender. Far from being a social equaliser, wars accentuate and reinforce vertical and horizontal social inequalities in multiple ways. Well informed social policies that respond to complex social realities are clearly needed to reverse these trends and facilitate the process of post-war recovery in this island nation.

\section{References}

Anderson, B. (1983). Imagined communities: reflections on the origin and spread of nationalism. London: Verso.

Arasaratnam, S. (1978). Social history of a dominant caste society, Indian Economic and Social History Review, 18, 377-91.

Arasaratnam, S. (1982). The historical foundations of the economy of the Tamils of North Sri Lanka. Jaffna: Thantai Chelva Memorial Trust.

Banks, M. (1960). Caste in Jaffna, in Leach. E.R. (ed) Aspects of caste in South India, Ceylon, and North-West Pakistan. Cambridge: Cambridge University Press, pp. 61-76.

Chatterjee, P. (1986). Nationalist thought and the colonial world: a derivative discourse? Tokyo: United Nations University.

Chatterjee, P. (1993). The nation and its fragments: colonial and postcolonial histories. Princeton: Princeton University Press.

Cheran, R. (2001). The sixth genre: memory, history and the Tamil diaspora imagination. Colombo: Marga Institute.

David, K. (1976). Hierarchy and equivalence in Ceylon: normative code as mediator in David, K. (ed), The new wind: changing identities in South Asia. The Hague: Mouton, pp. 179-226

Derges, J. (2013). Ritual and recovery in post-conflict Sri Lanka. London: Routledge.

Gill, T. (2007). Making things worse: how 'caste blindness' in Indian post-tsunami disaster recovery has exacerbated vulnerability and exclusion. Utrecht: Dalit Network of Netherlands.

Hellmann-Rajanayakam, D. (1989). Arumuka Navalar: religious reformer or national leader of Eelam, Journal of Indian Economic Social History Review, 26(2), 235-57.

Hellmann-Rajanayakam, D. (1990). The politics of the Tamils past, in Spencer, J. (ed), Sri Lanka: history and the roots of conflict. New York: Routledge.

Hellmann-Rajanayagam, D. (1993) Jaffna social system: continuity and change under condition of war. International Asienforum, 24 (3-4), 251-281.

Hellman-Rajanayakam, D. (1994). The Tamil Tigers: armed struggle for identity. London: F. Steiner.

Lall, A. (2015). Access to services in Jaffna: the role of caste. Paper presented in an open forum in the Centre for Poverty Analysis, Colombo in March 2015.

Perinbanayagam , R.S. (1982). The Karmic theatre: self, society and astrology in Jaffna. Amherst: The University of Massachusetts Press.

Pfaffenberger, B. (1981). The cultural dimension of Tamil separatism in Sri Lanka. Journal of Asian Survey 21(11), 1145-57.

Pfaffenberger, B. (1982). Caste in Tamil culture. New Delhi: Vikas, pp. 35-59.

Pfaffenberger, B. (1990). The political construction of defensive nationalism: The temple-entry crisis in northern Sri Lanka, The Journal of Asian Studies, 49(1), 78-96.

Pfaffenberger, B. (1994). Introduction in Manokaran, C. and Pfaffenberger, B. (eds), The Sri Lankan Tamils: ethnicity and identity. Boulder, CO: Westview.

Rajasingham, K.T. (2014, December 6) The woes of IDP in Valikamam, Asian Tribune. 
Räsänen, B.J. (2015). Caste and nation-building: constructing Vellalar identity in Jaffna. Gothenburg: University of Gothenburg, PhD thesis.

Ravikumar, V. (2002). Eelam and the Dalit question: caste of the tiger, Island of 2002-8-25 available at http://origin.island.lk/2002/08/25/featur12.html (accessed September 10, 2019).

Silva, K. T. (2018). Sex ratio and vulnerability in Northern and Eastern Provinces: Background Paper No 2 to the 'Socio-Economic Assessment of the Conflict Affected Northern and Eastern Provinces' conducted by the World Bank. Kandy: International Centre for Ethnic Studies.

Silva, K.T. (2017) Ethnicity, caste and the failure of war-related long-term IDPs to escape their plight. Panjab University Research Journal, 44 (1-2), 1-16.

Silva, K.T., Sivapragasam, P.P. \& Thanges, P. (eds) (2009). Casteless or caste-blind? Dynamics of concealed caste discrimination, social exclusion and protest in Sri Lanka. Colombo: Kumaran Press.

Sivathamby, K. (1995). Sri Lankan Tamil Society and Politics. Madras: New Century Book House (P) Ltd.

Thanges, P. (2013). Caste and social exclusion of IDP in Jaffna society. (Unpublished paper)

Thanges, P. (2015, December 8) Caste and camp people in Jaffna: land ownership and landlessness. Colombo Telegraph.

Thanges, P. \& Silva, K.T. (2009) Caste discrimination in war-affected Jaffna society, in Silva, K.T., Sivapragasam, P.P. \& Thanges, P. (eds) Casteless or caste-blind? dynamics of concealed caste discrimination, social exclusion and protest in Sri Lanka. Colombo: Kumaran Press, pp. 50-77.

Thorat, S. and Madheswaran, S. (2018). Graded caste inequality and poverty: evidence on role of economic discrimination, Journal of Social Inclusion Studies, 4(1), 3-2.

\section{Endnotes}

1. The author thanks Dr. Thanges Paramsothy of University of East London, Mr. S. Sivakanthan of the Department of Sociology, Jaffna University, and Mr. S. Sutharsan of the District Secretariat in Jaffna for their assistance during various stages of development of this study and analysis of the findings.

2. Parai drum is often used as a symbol of Paraiyar caste and Panchamar identity in general.

3. The estimated size of Panchamar population in pre-war Jaffna society ranges from 20 to 30 percent of the total population (Silva, Sivapragasam and Thanges 2009). Their relative strength in the population in the Peninsula reportedly increased during the war due to the large scale outmigration of Vellalar and members of middle level castes. Some authors have estimated that they comprise roughly about 50 percent of post-war population in Jaffna (Ravikumar, 2002).

4. A similar situation has been reported for a non IDP Panchamar community in Jaffna by Aftab Lall (2015) 